\title{
The Potential Use of Secondary Metabolites in Moringa oleifera as an Antioxidant Source
}

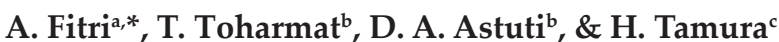 \\ aStudy Program of Nutrition and Feed Science, Faculty of Animal Science, Graduate School, \\ Bogor Agricultural University \\ ${ }^{b}$ Department of Nutrition and Feed Technology, Faculty of Animal Science, Bogor Agricultural University \\ Jalan Agatis, Kampus IPB Darmaga Bogor 16680, Indonesia \\ 'Department of Applied Biological Science, Faculty of Agriculture, Kagawa University \\ Miki-cho, Kagawa 761-0795, Japan \\ (Received 26-06-2015; Reviewed 07-08-2015; Accepted 17-09-2015)
}

\begin{abstract}
This present study determined antioxidant activity, lipid peroxidation, total phenolic, total flavonoids and phytochemicals in moringa leaves and moringa stem. Analysis used in this study was 1, 1-diphenyl-2-picrylhydrazyl (DPPH) method for antioxidant activity, thiobarbituric acid reactive substances (TBARS) method for lipid peroxidation, Folin-Ciocalteu method for total phenolic, total flavonoid and UFLC (Ultrafast Liquid Chromatography) for identification and quantification of phenolic compounds. The results showed that moringa leaves had higher ability to scavenge free radical, total phenolic, and total flavonoid than moringa stem $(\mathrm{P}<0.001)$. Malondialdehyde production, the end product of lipid peroxidation, in moringa leaves was lower than moringa stem $(\mathrm{P}<0.001)$. Ferulic acid was the major active compound in both moringa leaves and moringa stem. This present study indicated that moringa leaves and moringa stem could be used as feed additive which had a good potential to prevent oxidative stress in animals.
\end{abstract}

Key words: antioxidant, lipid peroxidation, moringa leaves, moringa stem, phytochemicals

\section{ABSTRAK}

Penelitian ini dilakukan untuk mengidentifikasi aktivitas antioksidan, peroksidasi lemak, total fenolik, total flavonoid, dan senyawa fenolik yang terdapat pada daun kelor dan batang kelor. Analisis yang digunakan dalam penelitian ini adalah analisis aktivitas antioksidan (metode DPPH atau 1, 1-diphenyl-2-picrylhydrazyl), analisis peroksidasi lemak (metode TBARS), analisis total fenolik (metode Folin-Ciocalteu), analisis total flavonoid, identifikasi dan kuantifikasi senyawa fenolik (Ultrafast Liquid Chromatography). Hasil menunjukkan bahwa daun kelor memiliki kemampuan dalam meredam radikal bebas (DPPH) lebih tinggi daripada batang kelor $(\mathrm{P}<0,001)$. Produksi malondialdehida pada proses peroksidasi lemak pada sampel daun kelor lebih rendah daripada batang kelor $(\mathrm{P}<0,001)$. Kandungan total fenolik dan flavonoid pada daun kelor lebih tinggi dibandingkan batang kelor. Asam ferulat merupakan senyawa fenolik yang paling banyak di daun dan batang kelor. Penelitian ini mengindikasikan bahwa daun kelor dan batang kelor dapat digunakan sebagai pakan suplementasi yang berpotensi dalam mencegah terjadinya oksidatif stress di ternak.

Kata kunci: antioksidan, peroksidasi lemak, daun kelor, batang kelor, fitokimia

\section{INTRODUCTION}

A tropical country like Indonesia has temperatures ranging from 23 to $33^{\circ} \mathrm{C}$ and humidity of $45 \%-97 \%$ (BMKG, 2013). In the tropics, with a combination of high ambient temperatures and humidity, livestock are prone

${ }^{*}$ Corresponding author:

E-mail: ainissya fitri@yahoo.co.id to heat stress. Heat stress can cause a lowered production and high mortalities leading to economic losses at farm level. Oxidative stress occurred because the production of free radicals is higher than the antioxidant defense system in the body. Free radicals can damage cell walls and impair the function of organs that play crucial roles in the body's metabolic system (Yoshikawa \& Naito, 2002). Oxidative stress in animals can inhibit growth rate, decrease appetite, decrease nutrient digestibility, impair the function of the immune system, 
decrease the production quality, and increase animals mortality (Sugito et al., 2007; Rajani et al., 2011; Hashemi et al., 2012).

The antioxidants could counteract free radicals thus it could prevent oxidative damage in the cells. There are two principle mechanisms of antioxidant action. The first is the primary antioxidant donates an electron to the free radicals and the second is removal of the secondary antioxidant by quenching chain-initiating catalyst (Lobo et al., 2010). Some studies have already proven that using antioxidant for animals could give a positive impact on health and production (Rajani et al., 2011; Hashemi et al., 2012). Antioxidant compounds can be found in the plant that it has phytochemical substances such as $\alpha$-tocopherol, $\beta$-carotene, ascorbic acid, flavonoids, carotenoids, anthocyanins, phenolic compounds, zinc and selenium (Moyo et al., 2012; Atowadi et al. 2010). In addition, the natural antioxidant sources is the most recommended to be used for animals feeding.

Moringa oleifera (moringa) is widely cultivated in many locations in the tropics. Moringa leaves contain protein, $\beta$-carotene, vitamins $\mathrm{A}, \mathrm{B}, \mathrm{C}$ and $\mathrm{E}$, minerals, steroids, alkaloids, quercetin and kaempferol. Several studies have proven that moringa leaves have several functions as antioxidant, anticancer, anti-atherosclerotis, anti-inflammatory, antitumor, to regulate thyroid status, improve growth performance in broiler chickens, improve the immune system (Chumark et al., 2008; Iqbal \& Bhanger 2006; Nkukwana et al., 2014; Verma et al., 2009; Rao et al., 2001; Sreelatha et al., 2011). Moringa leaves and fruits have high nutrients contents and advantageous for health, it is not only used for human food but also for animal feed. In order not to compete with human being, some parts of moringa plant can be used as animal feed such as stem and middle to old leaf. Thus the objectives of this study are to evaluate antioxidant activity in moringa leaves and moringa stem that can be used for animals feed.

\section{MATERIALS AND METHODS}

\section{Plant Materials}

Moringa forage was collected from Bekasi, West Java, Indonesia. The samples were obtained in February 2014. Moringa forage consisted of leaves and twigs that were at least the third branch and smaller. The moringa forage was separated into leaves and stems. The stems were twigs or small branches that were not more than 1 $\mathrm{cm}$ in diameter. All samples were dried at $50^{\circ} \mathrm{C}$ for $24 \mathrm{~h}$ and were ground to a fine powder.

\section{Plant Extract Preparation}

In a polypropylene centrifuge tube $(50 \mathrm{~mL})$ containing $2 \mathrm{~g}$ of powdered samples, $10 \mathrm{~mL}$ of distilled water and $15 \mathrm{~mL}$ of acetonitrile were added. This extraction method called QuEChERS (quick, easy, cheap, effective, rugged and safe) method that is normally used for determining of pesticides residues in agricultural product. However, with a little modification this method can also be used to analyze the chemical compound in foods
(Sato et al., 2015). The solution was homogenized for 1 min at $1000 \mathrm{rpm}$, followed by the addition of sodium chloride $(1 \mathrm{~g})$, trisodium citrate dehydrate $(1 \mathrm{~g})$, disodium hydrogen citrate sesquihydrate $(0.5 \mathrm{~g})$, and anhydrous magnesium sulfate $(4 \mathrm{~g})$ and then shaked it for 1 min. Then, the mixture was centrifuged at $3000 \mathrm{rpm}$ for $5 \mathrm{~min}$. The acetonitrile extract was evaporated and dried with a vacuum pump. The extracts were stored at $-20^{\circ} \mathrm{C}$. The amounts of extracts obtained from moringa leaves and moringa stem were $4.6 \%$ and $2.1 \%$, respectively.

\section{Analysis of DPPH Free Radical Scavenging Activity}

The effect of extracts and standard solution (Trolox) on the DPPH (1, 1-diphenyl-2-picrylhydrazyl) were determined by using method described by Zhu et al. (2014). Samples were diluted with methanol and acetic acid buffer (1:1). A volume of $0.25 \mathrm{~mL}$ of extracts or the standard in different concentrations $(200,100,50,10,5$, $1 \mu \mathrm{g} / \mathrm{mL}$ ) was mixed with $0.25 \mathrm{~mL}$ of acetic acid buffer $(0.10 \mathrm{M}), 0.25 \mathrm{~mL}$ of methanol and $0.25 \mathrm{~mL}$ of DPPH $(0.4$ $\mathrm{mM}$ in methanol). The reaction mixtures were vigorously mixed and incubated for $30 \mathrm{~min}$ at room temperature in the dark. The absorbance of mixtures was measured by spectrophotometer at $517 \mathrm{~nm}$. The $\mathrm{SC}_{50}$ (scavenging capacity in $50 \%$ ) value was determined by GraphPad PRISM 6 from the output of scavenging activity values. Each sample was done in triplicates. The $\mathrm{SC}_{50}$ value was expressed as $\mu \mathrm{g} / \mathrm{mL}$.

\section{Lipid Peroxidation Analysis (TBARS Assay)}

Lipid peroxidation inhibition was measured by using a thiobarbituric acid (TBA) method (Tamura \& Yamagami, 1994). A $100 \mu \mathrm{L}$ of each sample solution (10 $\mathrm{mg} / \mathrm{mL}$ ) and linoleic acid (5 mg) was mixed with $4.8 \mathrm{~mL}$ of $0.2 \%$ SDS Tris- $\mathrm{HCl}$ buffer. Then, $100 \mu \mathrm{L}$ of $20 \mathrm{mM}$ ferrous sulfate aqueous solution was added and the mixture was incubated for $16 \mathrm{~h}$ at $37^{\circ} \mathrm{C}$. The production of TBARS, mainly malondialdehyde, was measured in the following way. One $\mathrm{mL}$ of the reaction solution above was mixed with $3 \mathrm{~mL}$ of $0.05 \mathrm{~N} \mathrm{HCl}$ and $1 \mathrm{~mL}$ of $0.05 \mathrm{M}$ TBA- $50 \%$ acetic acid and then incubated for 30 $\mathrm{min}$ at $100^{\circ} \mathrm{C}$. After cooling to room temperature, $4 \mathrm{~mL}$ of $n$-butanol was added and the mixtures were shaken vigorously and added $200 \mu \mathrm{L}$ of EtOH. The mixtures were centrifuged (10 min, $2500 \mathrm{rpm}$ ) and the absorbance of the $n$-butanol layer was measured at $535 \mathrm{~nm}$. To make a standard curve, 1, 1, 3, 3-tetraethoxypropane standard solution $(0,2.5,5,10,20,30,40,50,60,70,80 \mathrm{nmol} / \mathrm{mL})$ were measured. Lipid peroxidation was expressed in nmol of MDA per $1 \mathrm{mg}$ of linoleic acid (nmol MDA/mg linoleic acid).

\section{Total Phenolic Content (TPC) Analysis}

Total phenolic content was estimated by following the procedure of Folin-Ciocalteu by Asada \& Tamura (2012) with slight modification. A $20 \mu \mathrm{L}$ of extracts $(1$ $\mathrm{mg}$ in $1 \mathrm{~mL}$ methanol) was mixed with $200 \mu \mathrm{L}$ of $50 \%$ phenol reagent, $200 \mu \mathrm{L}$ of $10 \%$ sodium carbonate aqueous solution, and $800 \mu \mathrm{L}$ of distilled water. The mixture 
was stored for $1 \mathrm{~h}$ in the dark place at room temperature. Then the absorbance was read at $760 \mathrm{~nm}$ with spectrophotometer by $5 \mathrm{~mm}$ length of a quartz cell using an UV-vis spectrophotometer (JASCO V-520-SR). A calibration curve was prepared with standard gallic acid $(0,200,400,600,800$, and $1000 \mu \mathrm{g} / \mathrm{mL})$ and the results were expressed as $\mathrm{mg}$ gallic acid equivalent (GAE) per $\mathrm{g}$ of extract (mg GAE/g dry extract).

\section{Total Flavonoid Content (TFC) Analysis}

Total flavonoid content was measured following the method of Poudel et al. (2008), using quercetin as a standard. A volume of $0.25 \mathrm{~mL}$ of the sample $(5 \mathrm{mg}$ in $1 \mathrm{~mL} 95 \%$ ethanol) or standard solution of quecertin $(1-0.0625 \mathrm{mg} / \mathrm{mL})$ was pipetted in a test tube and mixed with $0.25 \mathrm{~mL} 0.1 \% \mathrm{HCl}$ in $95 \%$ ethanol (v/v) and $4.55 \mathrm{~mL}$ $2 \% \mathrm{HCl}(\mathrm{v} / \mathrm{v})$. The solution was incubated for $15 \mathrm{~min}$ and the absorbance was read at $360 \mathrm{~nm}$ with a spectrophotometer. Total flavonoid content was expressed as mg quercetin equivalent per $g$ of extract (mg QE/g dry extract).

\section{Ultrafast Liquid Chromatography (UFLC) Analysis}

The UFLC analysis of all samples was carried out on a Shimadzu UFLC system equipped with LC-20AD pump and SPD-M20A detector. The separation was performed on a Mightysil RP-18 GP column (3.0 mm i. $\mathrm{d} \times 100 \mathrm{~mm}$ ). The mobile phases were $10 \% \mathrm{CH}_{3} \mathrm{CN}-0.5 \%$ TFA as eluent $\mathrm{A}$ and $100 \% \mathrm{CH}_{3} \mathrm{CN}-0.5 \%$ TFA as eluent $\mathrm{B}$. The flow rate was fixed at $0.5 \mathrm{~mL} / \mathrm{min}$ and the column temperature was set at $40{ }^{\circ} \mathrm{C}$. A gradient program was performed as follows: $0 \mathrm{~min}, 100 \%$ (A); $1 \mathrm{~min}, 100 \%$ (A); $2 \mathrm{~min}, 85 \%(\mathrm{~A}) ; 6 \mathrm{~min}, 85 \%(\mathrm{~A}) ; 14 \mathrm{~min}, 0 \%(\mathrm{~A}) ; 18 \mathrm{~min}$, $0 \%(\mathrm{~A}) ; 19 \mathrm{~min}, 100 \%$ (A). The UV spectra were recorded between 190 and $600 \mathrm{~nm}$ for peak characterization. Phenolic compounds were quantified by the peak area of maximum absorption wavelength, respectively.

\section{Statistical Analysis}

All data were expressed as mean \pm standard deviation (SD) in triplicate at least. For comparisons between

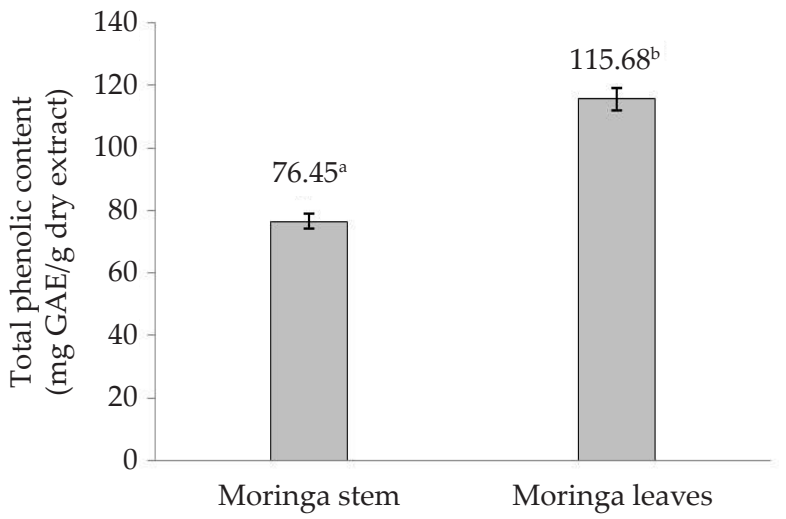

Figure 1. Total phenolic content in moringa leaves and moringa leaves $(n=4)$. Means with different superscript are significantly different $(\mathrm{P}<0.001)$. samples, data were analyzed by ANOVA and Duncan test (SPSS, version 16.0). A probability of $5 \%$ or less was accepted as statistically significant.

\section{RESULTS AND DISCUSSION}

\section{Total Phenolic Content and Total Flavonoid Content}

Phenolic compounds are secondary metabolites in fruits or plants. These compounds are derivatives of the pentose phosphate, shikimate, and phenylpropanoid pathways in plants (Randhir et al., 2004). Phenolics, including flavonols, flavones, phenolic acids, proanthocyanidins and tannins, are reported as the major contributors to the biological properties like antioxidant activities of moringa leaves (Astuti et al., 2011; Vongsak et al., 2013).

The results of TPC values in this study are presented in Figure 1. The TPC in moringa leaves (115.68 mg GAE/g dry extract) was significantly higher than moringa stem (76.45 mg GAE/g dry extract). Moyo et al. (2012) reported phenolic content in moringa leaves extracted with acetone (120.33 mg tannin equivalent (TE)/g dry extract) was higher than extracted with aqueous (40.27 mg TE)/g dry extract). The TPC of moringa leaves was $105 \mathrm{mg}$ GAE/g in aqueous extracts (Singh et al. 2009), $103 \mathrm{mg}$ GAE/g in methanol extracts, 97.2 mg GAE/ $\mathrm{g}$ in ethanol extracts (Sultana et al., 2014) and $123.3 \mathrm{mg} \mathrm{GAE} / \mathrm{g}$ in $80 \%$ methanol extracts (Siddhuraju \& Becker, 2003).

Quecertin and kaempferol are the major flavonoid compounds reported in this plant (Singh et al., 2009; Atowadi et al., 2010; Sultana \& Anwar, 2008). In this paper, quecertin was used as a standard chemical to measure total flavonoid. Quecertin is one of flavonoid compound in flavonols group and is abundant in fruit and vegetables. Quecertin was reported had a great antioxidant and antiallergic activity (Sato et al., 2015; Singh et al., 2009). All samples tested showed significantly differences to the total flavonoid value $(\mathrm{P}<0.001)$. Moringa leaves (113.95 mg QE/g dry extract) had the highest flavonoid content, followed by moringa stem (66.16 mg QE/g dry extract) (Figure 2). Moyo et al. (2012) reported flavonoid content in moringa leaves extracted with

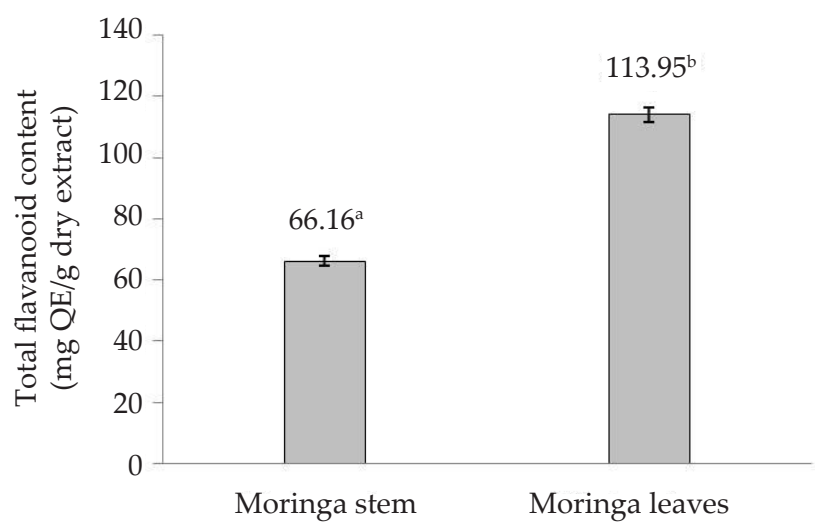

Figure 2. Total flavonoid content in moringa leaves and moringa stem $(n=4)$. Means with different superscript are significantly different $(\mathrm{P}<0.001)$. 
acetone (295.01 mg QE/g dry extract) was higher than extracted with aqueous (45.1 mg QE/g dry extract).

These differences could be due to several factors such as type of cultivation, climate, fruit variety, geographic origin, ripeness and extraction method (Deng et al. 2010; Vasco et al., 2008). All samples tested could be considered as a good source of phenolic compounds and antioxidants. Phenolic compounds as free radical scavengers could be due to their redox properties, presence of conjugated ring structures and carboxylic group which have been reported to inhibit lipid peroxidation (Oyedemi et al., 2010).

Moyo et al. (2012) reported that supplementation of $200 \mathrm{~g}$ powder of moringa leaves (equal to $0.5 \mathrm{~g}$ quecertin/g extract) increased antioxidant enzymes in goats such as glutathione, superoxide dismutase and catalase. The supplementation of moringa leaves and moringa stems could also be safely used as a source of antioxidant in goats feed and the others animals (Sultana et al., 2014).

\section{DPPH Radical Scavenging Activity}

The method of DPPH radical scavenging activity to evaluate the antioxidant activity is an established procedure and is widely used to estimate the antioxidant activities of food. This method is easy to handle, low cost, reasonably and fast method to evaluate radical scavenging activity (Sharma \& Bhat, 2009). This assay has also been used to establish antioxidant activity of herbal extract and phytochemicals (Moyo et al., 2012).

The result of DPPH radical scavenging activity is interpreted with $\mathrm{SC}_{50}$ values. All samples had an activity to scavenge free radicals (Figure 3 ). The $\mathrm{SC}_{50}$ values of DPPH of moringa leaves $(27.02 \mu \mathrm{g} / \mathrm{mL})$ had lower than moringa stem $(62.31 \mu \mathrm{g} / \mathrm{mL})$, but trolox had the lowest values $\mathrm{SC}_{50}$ of $\mathrm{DPPH}(\mathrm{P}<0.001)$. The lower the $\mathrm{SC}_{50}$ value, the better the antioxidant activity. The $\mathrm{SC}_{50}$ of DPPH in moringa leaves extracted with $70 \%$ ethanol was $62.94 \mu \mathrm{g} / \mathrm{mL}$ (Vongsak et al., 2013). The differences of $\mathrm{SC}_{50}$ values of DPPH scavenging radical activity was possibly caused by different solvent used, cultivation, extraction method and varieties of plant. The high activity of antioxidant in moringa leaves was caused by the

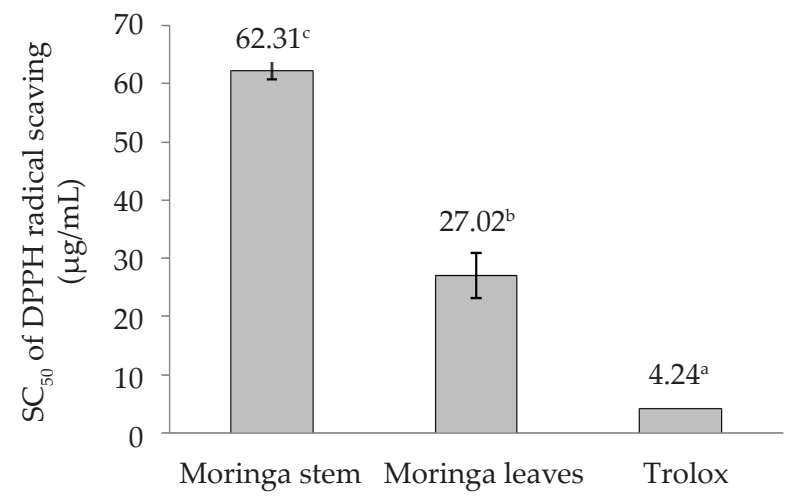

Figure 3. The $\mathrm{SC}_{50}$ of DPPH free radicals in moringa leaves and moringa stem $(n=3)$. Means with different superscripts are significantly different $(\mathrm{P}<0.001)$. high value of phenolic content and flavonoid content in this sample. Phenolic compounds in the sample have a linear correlation with antioxidant activity.

\section{Lipid Peroxidation}

Lipid peroxidation is one of the markers of oxidative stress. Lipid peroxidation is always occurred in polyunsaturated fatty acids such as linoleic acid, linolenic acid and arachidonic acid (cell membrane component) which are oxidized in various pathological conditions (Yoshikawa \& Naito, 2002). Malondialdehyde (MDA) and 4-hydroxy-2-hexenal (HHE) are the end products from lipid peroxidation process. These products have cytotoxic, mutagenic, and neurotoxic properties and can promote cancer development in the gastrointestinal (GI) tract and liver (Del Rio et al., 2005; Long \& Picklo, 2010).

The effects of moringa leaves and moringa stem on lipid peroxidation were summarized in Figure 4. In this study, there was a significant different in the effect of moringa leaves and moringa stem on lipid peroxidation $(\mathrm{P}<0.001)$. In lipid peroxidation, the lower value of MDA indicates the stronger activity of inhibited lipid peroxidation. The moringa leaves (4.9 nmol MDA/mg of linoleic acid) had the strongest activity for inhibiting of lipid peroxidation compared to moringa stem (7.77 nmol MDA/mg of linoleic acid).

The percentages of lipid peroxidation inhibition in moringa leaves and moringa stems were 85.88 and $77.63 \%$, respectively. Moringa leaves extracts that were used as goats feed inhibited lipid peroxidation by $81.33 \%$. This value was higher than used sunflower (38.76\%) and grass hay (1.99\%) (Moyo et al., 2012).

Supplementation of moringa leaf meal up to $5 \%$ of dry matter intake in broiler chickens could improve fatty acid profile and reduce lipid peroxidation in meat (Nkukwana et al., 2014). In addition, feeding 30\% of moringa in sheep ration increased glucose and triglycerides, increased albumin, globulin and IgG, and also decreased cholesterol (Astuti et al., 2011). It proved that inhibition of lipid peroxidation in moringa can improve product quality and health status in animals.

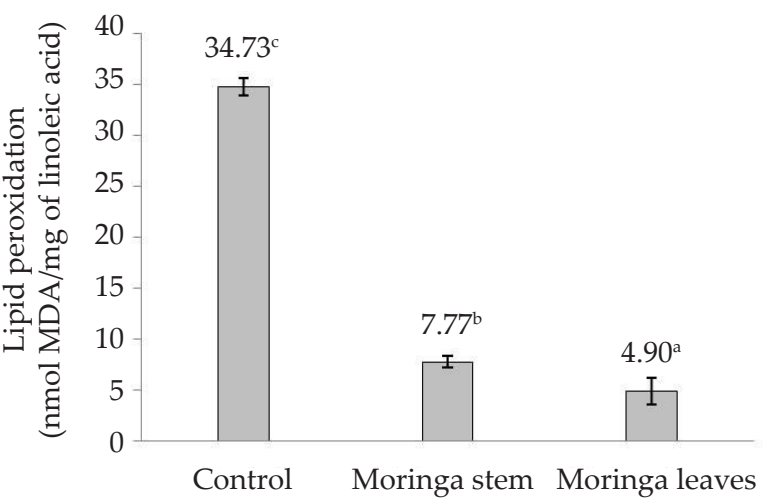

Figure 4. The lipid peroxidation in moringa leaves $(n=3)$, moringa stem $(n=3)$ and control $(n=4)$. Means with different superscripts are significantly different $(\mathrm{P}<0.001)$. 


\section{Ultrafast Liquid Chromatography (UFLC) Analysis}

In the present study, identification of chemical compounds in moringa leaves and stems was done by using UFLC. Some reference standards that were used in this study are representative of three main group of phenolics compound such hydroxybenzoic acids (gallic acid, protocatechuic acid, syringic acid, vanilic acid and 4-hidroxybenzoic acid), hydroxycinnamic acids (caffeic acid, ferulic acid, p-coumaric acid, o-coumaric acid, cinnamic acid and chlorogenic acid), and flavonoids (rutin and quercetin).

Figure 5 (A) shows the chromatogram of standard compounds monitored at different wavelengths, selected on the basis of maxima absorbance and maximum of peak area (Arimboor et al., 2008; $\mathrm{Zu}$ et al., 2006). The chromatogram of some standards was overlapped such as VA, SA and CgA, 4-HA, possibly because these stan- dards were eluted closely. However, using absorption maxima we were able to compare them. For VA and SA, their chromatogram showed that SA had highest absorbance at $269 \mathrm{~nm}$ and smaller at $290 \mathrm{~nm}$, this wavelength would be the detection wavelength for VA. So, the detection wavelength for 4-HA is at $260 \mathrm{~nm}$ and $\mathrm{CgA}$ is at $338 \mathrm{~nm}$.

Table 1 showed the phenolic compounds in moringa leaves and moringa stem (Figure $5 \mathrm{~B}$ and $5 \mathrm{C}$ ). Ferulic acid was the most abundant phenolic compounds in moringa leaves (46.8 mg/g dry extract) and moringa stem $(10.0 \mathrm{mg} / \mathrm{g}$ dry extract). Chlorogenic acid, rutin, quecertin, caffeic acid was predominantly phenolic compounds in moringa leaves. Then in the moringa stem, rutin was the second most of phenolic compounds in this study. It is possible that ferulic acid, chlorogenic acid, rutin, quecertin, caffeic acid provided strong scavenging free radicals and inhibition lipid peroxidation.
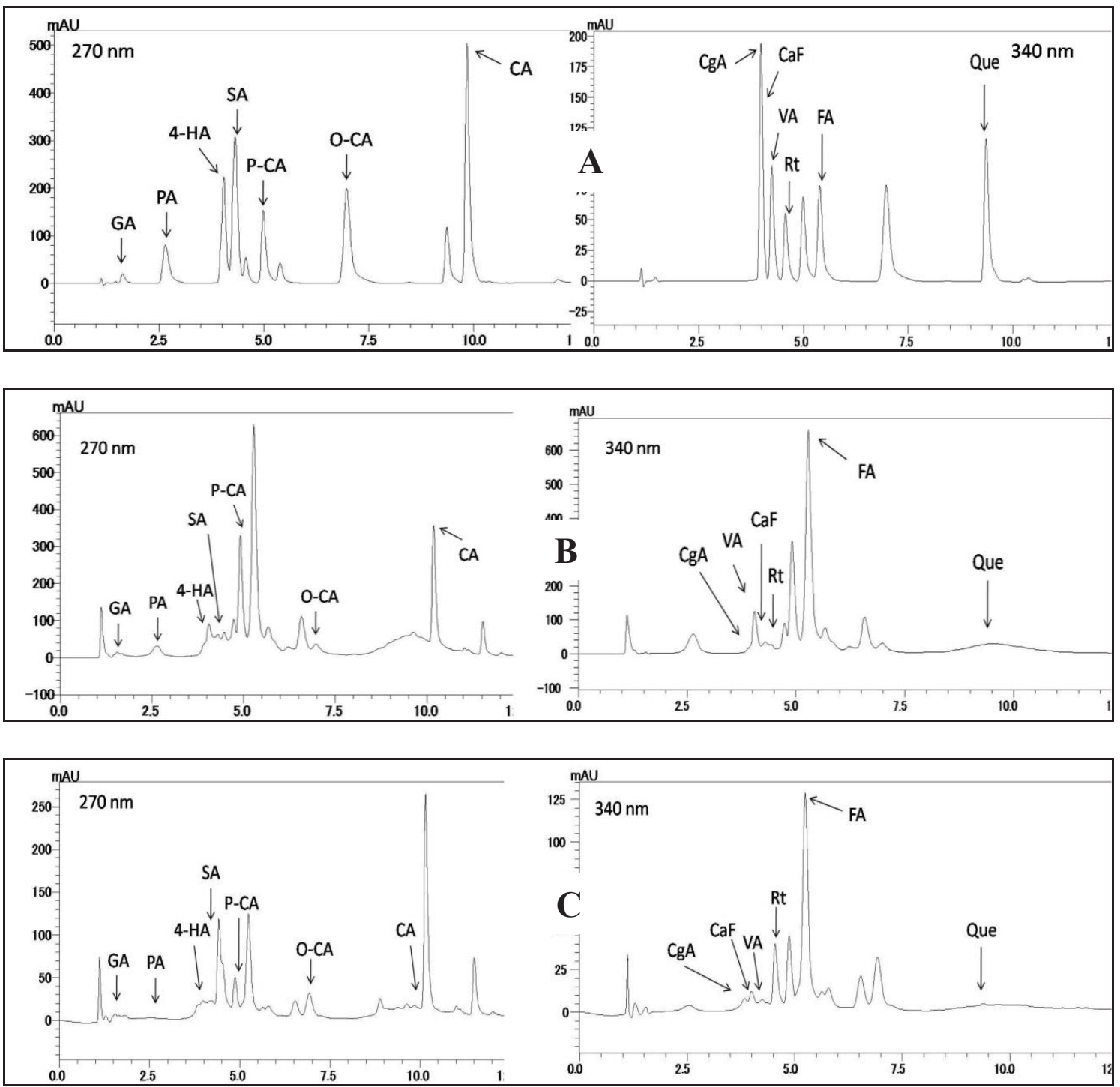

Figure 5. The chromatograms of standard reference of phenolic compounds (A), moringa leaves (B) and moringa stem (C) in the 270 and $340 \mathrm{~nm}$. CA, caffeic acid; GA, gallic acid; PA, protocatechuic acid; 4-HA, 4-hidroxybenzoic acid; SA, syringic acid; Rt, rutin; p-CA, p-coumaric acid; FA, ferulic acid; o-CA, o-coumaric acid; Que, quercetin; CA, cinnamic acid; VA, vanilic acid; $\mathrm{CgA}$, chlorogenic acid. 
Table 1. Wavelength detection $(\lambda)$, retention time $(\mathrm{rT})$, regression equation, and quantification of phenolic compounds in moringa leaves and moringa stems

\begin{tabular}{|c|c|c|c|c|c|c|}
\hline \multirow[t]{2}{*}{ Compounds } & \multirow[t]{2}{*}{$\lambda(\mathrm{nm})$} & \multirow{2}{*}{$\begin{array}{c}\mathrm{rT} \\
(\mathrm{min})\end{array}$} & \multirow{2}{*}{ Regression equation } & \multirow[t]{2}{*}{$\mathrm{r}$} & \multicolumn{2}{|c|}{$\begin{array}{c}\text { Amount of compound } \\
\text { (mg/g dry extract) }\end{array}$} \\
\hline & & & & & Moringa leaves & Moringa stem \\
\hline 4-HA & 251 & 4.0 & $y=1126 x+37.45$ & 0.994 & 5.3 & 3.3 \\
\hline CA & 280 & 9.8 & $y=1588 x+12.6$ & 0.993 & 5.5 & 0.2 \\
\hline $\mathrm{CaF}$ & 320 & 4.2 & $y=378.3 x+3.175$ & 0.996 & 10.1 & 2.6 \\
\hline $\mathrm{CgA}$ & 320 & 3.9 & $y=463.5 x+13.64$ & 0.988 & 18.0 & 0.5 \\
\hline FA & 320 & 5.3 & $y=490.1 x+5.242$ & 0.988 & 46.8 & 10.0 \\
\hline GA & 270 & 1.7 & $y=228.4 x+3.311$ & 0.976 & 3.0 & 0.5 \\
\hline $\mathrm{o}-\mathrm{CA}$ & 280 & 6.9 & $y=1077 x+5.942$ & 0.994 & 2.8 & 1.5 \\
\hline PA & 260 & 2.6 & $y=521.5 x+15.54$ & 0.997 & 3.13 & 0.04 \\
\hline $\mathrm{p}-\mathrm{CA}$ & 300 & 4.9 & $y=1231 x+8.267$ & 0.994 & 7.0 & 0.9 \\
\hline Que & 350 & 9.4 & $y=516.5 x+1.597$ & 0.994 & 13.3 & 0.8 \\
\hline Rt & 350 & 4.5 & $y=184.9 x+0.443$ & 0.996 & 16.9 & 8.9 \\
\hline SA & 260 & 4.2 & $y=1217 x+9.580$ & 0.994 & 1.3 & 2.6 \\
\hline VA & 290 & 4.2 & $y=1036 x+7.751$ & 0.995 & 2.7 & 0.9 \\
\hline
\end{tabular}

Note: $\mathrm{CA}=$ caffeic acid; $\mathrm{GA}=$ gallic acid; $\mathrm{PA}=$ protocatechuic acid; 4 -HA=4-hidroxybenzoic acid; $\mathrm{SA}=$ syringic acid; $\mathrm{Rt}=$ rutin; $\mathrm{p}-\mathrm{CA}=\mathrm{p}$-coumaric acid; $\mathrm{FA}=$ ferulic acid; $\mathrm{o}-\mathrm{CA}=\mathrm{o}$-coumaric acid; $\mathrm{Que}=$ quercetin; $\mathrm{CA}=$ cinnamic acid; $\mathrm{VA}=$ vanilic acid; $\mathrm{CgA}=$ chlorogenic acid.

\section{CONCLUSION}

Moringa leaves and moringa stem had the ability to scavenge free radicals and to inhibit lipid peroxidation. Total phenolic and flavonoids content in moringa leaves were higher than moringa stem. Ferulic acid and rutin were found in both samples. Although the moringa stem had lower activity than moringa leaves, but both of them could be used as feed supplement (100 g of moringa leaves powder or $360 \mathrm{~g}$ of moringa stem powder) to improve health status in animals.

\section{ACKNOWLEDGEMENT}

This study was done in Department of Applied Biological Science, Faculty of Agriculture, Kagawa University, Japan. This study was also supported by Japan Student Services Organization (JASSO) Scholarship.

\section{REFERENCES}

BMKG. Badan Metereologi, Klimatologi dan Geofisika. 2013. Prakiraan cuaca Indonesia. http://www.bmkg.go.id/ BMKG_Pusat/Meteorologi/Prakiraan_Cuaca_Indonesia. bmkg [13 Februari 2014]

Arimboor R, K. S. Kumar, \& C. Arumughan. 2008. Simultaneous estimation of phenolic acids in sea buckthorn (Hippophae rhamnoides) using RP-HPLC with DAD. J. Pharm. \& Biomed. Anal. 47: 31-38. http://dx.doi.org/10.1016/j. jpba.2007.11.045

Asada, T. \& H. Tamura. 2012. Isolation of bilberry anthocyanidin 3-glycosides bearing ortho-dihydroxyl groups on the $b$ ring by forming an aluminum complex and their antioxidant activity. J. Agric. Food Chem. 60: 10634-10640. http:// dx.doi.org/10.1021/jf302476n

Astuti, D. A., A. S. Baba, \& I. W. T. Wibawan. 2011. Rumen fermentation, blood metabolites, and performance of sheep fed tropical browse plants. Med. Pet. 34: 201-206. http:// dx.doi.org/10.5398/medpet.2011.34.3.201
Atowadi, S. E., J. C. Atowadi, G. A. Idakwo, B. Pfundstein, R. Haubner, G. Wurtele, H. Bartsch, \& R. W. Owen. 2010. Evaluation of the polyphenol content and antioxidant properties of methanol extracts of the leaves, stem, and root barks of Moringa oleifera Lam. J. of Medicinal Food. 13: 710-716. http://dx.doi.org/10.1089/jmf.2009.0057

Chumark P., P. Khunawat, Y. Sanvarinda, S. Phornchirasilp, N. P. Morales, L. Phivthong-ngam, P. Ratanachamnong, S. Srisawat, \& K. S. Pongrapeeporn. 2008. The in vitro and ex vivo antioxidant properties, hypolipidaemic and antiatherosclerotic activities of water extract of Moringa oleifera Lam. leaves. J. Ethnopharm. 116: 439-446. http://dx.doi. org/10.1016/j.jep.2007.12.010

Del Rio, D., A. J. Stewart, \& N. Pellegrini. 2005. A review of recent studies on malondialdehyde as toxic molecule and biological marker of oxidative stress. Nutr., Metab. Cardiovasc. Dis. 15: 316-328. http://dx.doi.org/10.1016/j.numecd.2005.05.003

Deng, S., B. J. West, \& C. J. Jensen. 2010. A quantitative comparison of phytochemcial components in global noni fruits and their commercial products. Food Chem. 122: 267-270. http://dx.doi.org/10.1016/j.foodchem.2010.01.031

Hashemi, S.R., I. Zulkifli, H. Davoodi, Z. Zunita, \& M. Ebrahimi. 2012. Growth performance, intestinal microflora, plasma fatty acid profile in broiler chickens fed herbal plant (Euphorbia hirta) and mixed of acidifiers. Anim. Feed Sci. \& Tech. 178: 167-174. http://dx.doi.org/10.1016/j.anifeedsci.2012.09.006

Iqbal, S., \& M. I. Bhanger. 2006. Effect of season and production location on antioxidant activity of Moringa oleifera leaves grown in Pakistan. J. Food Comp. \& Anal. 19: 54455. http://dx.doi.org/10.1016/j.jfca.2005.05.001

Lobo, V., A. Patil, A. Phatak, \& N. Chandra. 2010. Free radicals, antioxidant and functional foods: Impact on human health. Pharmacogn. Rev. 4: 118-126. http://dx.doi. org/10.4103/0973-7847.70902

Long, E. K., \& M. J. Picklo. 2010. Trans-4-hydroxy-2-hexenal, a product of $\mathrm{n}-3$ fatty acid peroxidation: make some room HNE. Free Radical Biol. Med. 49: 1-8. http://dx.doi. org/10.1016/j.freeradbiomed.2010.03.015

Moyo, B., S. Oyedemi, P. J. Masika, \& V. Muchenje. 2012. Polyphenolic content and antioxidant properties of $\mathrm{Mo}$ ringa oleifera leaf extracts and enzymatic activity of liver 
from goats supplemented with Moringa oleifera leaves/ sunflower seed cake. Meat Sci. 91: 441-447. http://dx.doi. org/10.1016/j.meatsci.2012.02.029

Nkukwana, T. T., V. Muchenje, E. Pieterse, P. J. Masika, T. P. Mabusela, L. C. Hoffman, \& K. Dzama. 2014. Effect of Moringa oleifera leaf meal on growth performance, apparent digestibility, digestive organ size and carcass yield in broiler chickens. Livest. Sci. 161: 139-146. http://dx.doi. org/10.1016/j.livsci.2014.01.001

Oyedemi, S. O., G. Bradley, \& A. J. Afolayan. 2010. In-vitro and -vivo antioxidant activities of aqueous extract of Strychnos henningsii Gilg. Afr. J. Pharm. Pharmacol. 4: 70-78.

Poudel, P.R., H. Tamura, I. Kataoka, \& R. Mochioka. 2008. Phenolic compounds and antioxidant activities of peels and seeds of five wild grapes and two hybrids native to Japan. J. Food Comp. \& Anal. 21: 622-625. http://dx.doi. org/10.1016/j.jfca.2008.07.003

Rajani, J., M. A. K. Torshizi, \& S. Rahimi. 2011. Control of ascites mortality and improved performance and meat shelflife in broiler using feed adjuncts with presumed antioxidant activity. Anim. Feed Sci. \& Tech. 170: 239-245. http:// dx.doi.org/10.1016/j.anifeedsci.2011.09.001

Randhir, R., Y. T. Lin, \& K. Shetty. 2004. Phenolics, their antioxidant and antimicrobial activity in dark germinated fenugreek sprouts in response to peptide and phytochemical elicitors. Asia Pac. J. Clin. Nutr. 2004. 13: 295-307.

Rao, A. V., P. U. Devi, \& R. Kamath. 2001. In vitro radioprotective effect of Moringa oleifera leaves. Indian J. Exp. Biol. 39: 858-863.

Sato, A., T. Zhang, L. Yonekura, \& H. Tamura. 2015. Antiallergic activities of eleven onions (Allium cepa) were attributed to quercetin 4'-glucoside using QuEChERS method and Pearson's correlation coefficient. J. Functional Foods. 14: 581-589. http://dx.doi.org/10.1016/j.jff.2015.02.029

Sharma, O. P. \& T. K. Bhat. 2009. Analytical Methods; DPPH antioxidant assay revisited. Food Chem. 113: 1202-1205. http://dx.doi.org/10.1016/j.foodchem.2008.08.008

Siddhuraju, P. \& K. Becker. 2003. Antioxidant properties of various solvent extracts of total phenolic constituents from three different agroclimatic origins of drumstick tree ( $\mathrm{Mo}$ ringa oleifera lam.) leaves. J. Agric. Food Chem. 51: 21442155. http://dx.doi.org/10.1021/jf020444+

Singh, B. N., B. R. Singh, R. L. Singh, D. Prakash, R. Dhakarey, G. Upadhyay, \& H. B. Singh. 2009. Oxidative DNA damage protective activity, antioxidant and anti-quorum sensing potentials of Moringa oleifera. Food \& Chem. Toxic. 47: 1109-1116. http://dx.doi.org/10.1016/j.fct.2009.01.034
Sreelatha, S., A. Jeyachitra, \& P. R. Padma. 2011. Antiproliferation and induction of apoptosis by Moringa oleifera leaf extract on human cancer cells. Food Chem. Toxic. 49: 12701275. http://dx.doi.org/10.1016/j.fct.2011.03.006

Sugito, W. Manalu, D. A. Astuti, E. Handharyani, \& Chairul. 2007. Morfometrik usus dan performa ayam broiler yang diberi cekaman panas dan ekstrak n-heksana kulit batang "jaloh" (Salix tetrasperma Roxb). Med. Pet. 30: 198-206.

Sultana, B., \& F. Anwar. 2008. Flavonols (kaempeferol, quercetin, myricetin) contents of selected fruits, vegetables and medicinal plants. Food Chem. 108: 879-884. http://dx.doi. org/10.1016/j.foodchem.2007.11.053

Sultana, N., A. R. Alimon, K. S. Haque, A. Q. Sazili, H. Yaakub, \& S. M. J. Hossain. 2014. The effect of cutting interval on yield and nutrient composition of different plant fractions of Moringa oleifera tree. JFAE 12: 599-604.

Tamura, H., \& A. Yamagami. 1994. Antioxidative activity of monoacylated anthocyanins isolated from muscat bailey a grape. J. Agric. Food Chem. 42: 1612-1615. http://dx.doi. org/10.1021/jf00044a005

Vasco, C., J. Ruales, \& A. Kamal-Eldin. 2008. Total phenolic compounds and antioxidant capacities of major fruits from Ecuador. Food Chem. 111: 816-823. http://dx.doi. org/10.1016/j.foodchem.2008.04.054

Verma, A. R., M. Vijayakumar, C. S. Mathela, \& C. V. Rao. 2009. In vitro and in vivo antioxidant properties of different fractions of Moringa oleifera leaves. Food Chem. Toxic. 47: 21196-21201. http://dx.doi.org/10.1016/j.fct.2009.06.005

Vongsak, B, P. Sithisarn, S. Mangmool, S. Thongpraditchote, Y. Wongkrajang, \& W. Gritsanapan. 2013. Maximizing total phenolics, total flavonoids contents and antioxidant activity of Moringa oleifera leaf extract by the appropriate extraction method. Ind. Crops Prod. 44: 566-571. http:// dx.doi.org/10.1016/j.indcrop.2012.09.021

Yoshikawa T., \& Y. Naito. 2002. What is oxidative stress? JMAJ. 45: 271-276.

Zhu, F., T. Asada, A. Sato, Y. Koi, H. Nishiwaki, \& H. Tamura. 2014. Rosmarinic acid extract for antioxidant, antiallergic, and $\alpha$-glucosidase inhibitory activities, isolated by supramolecular technique and solvent extraction from perilla leaves. J. Agric. Food Chem. 62: 885-892. http://dx.doi. org/10.1021/jf404318j

Zu, Y., C. Li, Y. Fu, \& C. Zhao. 2006. Simultaneous determination of catechin, rutin, quercetin kaempferol and isorhamnetin in the extract of sea buckthorn (Hippophae rhamnoides L.) leaves by RP-HPLC with DAD. J. Pharm. Biomed. Anal. 41: 714-719. http://dx.doi.org/10.1016/j.jpba.2005.04.052 